\title{
FORGÁSSZIMMETRIKUS SZABAD LEVEGŐSUGÁR TURBULENS JELLEMZŐINEK KÍSÉRLETI ÉS NUMERIKUS VIZSGÁLATA
}

\author{
Szabó Szilárd - Bolló Betti - Baranyi László - Tollár Sándor - Szaszák Norbert
}

\begin{abstract}
Absztrakt: A szakirodalomban vizsgált szabad folyadék- és gázsugarak a legkülönfélébb átmérőjü, kialakítású és geometriai helyzetü fúvókákon érkeznek a szabadba. A kiömlési keresztmetszetre jellemző Reynolds szám is igen különböző. Amiben a közlemények megegyeznek, az az, hogy a szabad sugár áramlási jellemzőit, úgy, mint a sebességeloszlást és a turbulenciát jellemző mennyiségeket dimenziótlanítva, hasonlósági tulajdonságokat mutatnak ki. Jelen dolgozatban megvizsgáljuk, hogy e hasonlóságok igazak-e egy speciális fúvóka esetén, ahol három irányból érkező levegősugár egy keverőtérben egyesül és így hagyja el a fúvókát. A vizsgálatok párhuzamosan folytak laboratóriumi sebességmérésekkel (Constant Temperature Anemometry, CTA) és numerikus szimulációval (ANSYS-FLUENT). A mérési és a számítási eredményeket összevetettük és kellő egyezést találtunk. Továbbá eredményeinket összehasonlítottuk a szakirodalomban található, más fúvókákra és más körülmények között végzett mérések eredményeivel.
\end{abstract}

\begin{abstract}
Axisymmetric liquid and gas jets have been investigated in the literature issuing from nozzles of different diameters and different geometry. Reynolds numbers (calculated from the parameters at the exit of the nozzle) are also usually very different. What is common in these papers is that the dimensionless velocity distributions and turbulence properties in the axisymmetric jet show self-similar features some distance downstream of the nozzle. In this paper, we investigate whether these self-similar features are held for a special nozzle where three jets of different directions are merged and mixed in a chamber before leaving the nozzle. Experimental velocity measurements (by constant temperature anemometry, CTA) and numerical simulations (by ANSYS Fluent) were carried out simultaneously. Computational and experimental results showed satisfactory agreement. Our results also compared reasonably well with those in the literature, considering that they are based on different nozzles and different flow conditions.
\end{abstract}

Kulcsszavak: forgásszimmetrikus levegősugár, turbulencia, CTA, Ansys FLUENT

Keywords: axisymmetric air jet, turbulence, CTA, ANSYS Fluent

\section{Bevezetés}

A vizsgálat tárgya egy speciális fúvóka, amely kompresszor levegő (primer közeg) müködtetésével sólevet (szekunder közeg) szállít. Az áramlási járatokat és a föbb geometriai jellemzőket az 1 . ábrán tüntettük fel. A folyamat részletes megismeréséhez a primer levegő áramlását vizsgáltuk a szekunder sugár útjának lezárásával. A következőkben erről számolunk be. A levegő három irányból 0,7 mm átméröjü csöveken a $4 \mathrm{~mm}$ átméröjü keveredési térbe érkezik, amelyböl egy nagy kúpszögü nyíláson áramlik a szabadba.

A kitűzött célunk a fúvókából kilépő levegősugár áramlási adatainak, különös tekintettel a turbulenciát jellemző mennyiségeknek a meghatározása volt. A vizsgálatokat laboratóriumi és numerikus modellezéssel végeztük. A mérésekkel párhuzamosan, azokkal azonos körülmények közötti numerikus szimulációt hajtottunk végre a mozgás- és turbulencia paraméterek meghatározására. A mérési és számítási eredmények validálása után lehetőség lesz a numerikus modellekkel további fúvókák tervezésére. 


\section{1. ábra: A vizsgált fúvóka áramlási terei}

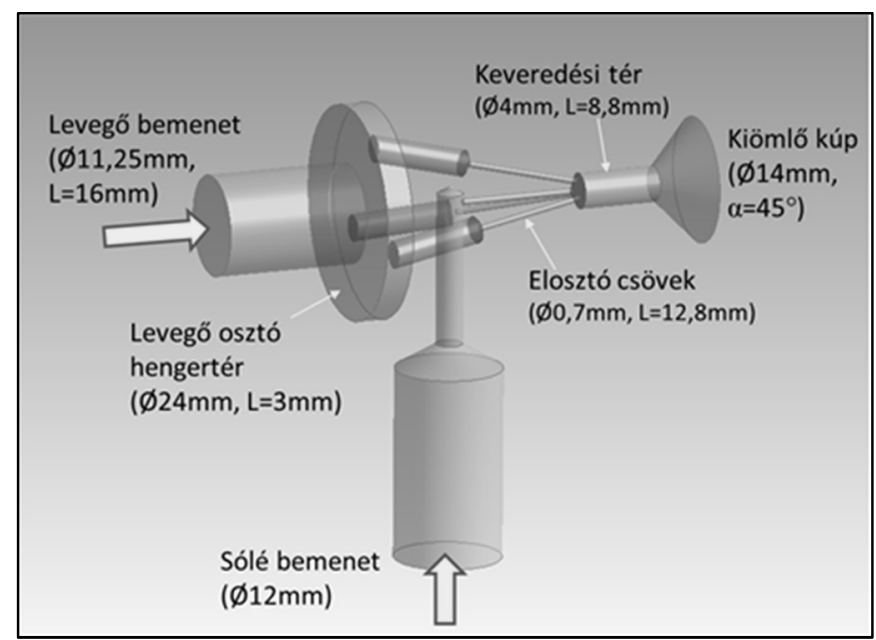

Forrás: A szerzők saját szerkesztése

\section{Irodalmi áttekintés}

A turbulens forgásszimmetrikus összenyomhatatlan vagy összenyomható folyadéksugár vizsgálatával gyakorlati fontossága miatt igen sok kutatócsoport foglalkozott. Reichardt (1942) igazolta, hogy a szabadsugarakban a fúvóka előtti különböző síkokban a dimenziótlan sebességeloszlások egymáshoz hasonlóak. Wygnanski és Fiedler (1969) kísérleti vizsgálatai során egy vízszintes tengelyü levegősugár jellemzőit Pitot-csővel és olyan hődrótos anemométerrel mérte, ahol a drót hőmérsékletét energia-betáplálással állandó értéken tartották. A korábbi vonatkozó vizsgálatokkal szemben ők linearizált állandó hőmérsékletủ (CTA) hődrótos anemométert használtak annak kiderítésére, hogy a sebességprofilok és a turbulens jellemzők hasonlósága a fúvóka kilépő keresztmetszetétől mért milyen távolságban teljesülnek. A sebességeloszlás időátlagára vonatkozó eredményeik jó egyezést mutatnak Hinze és Van Der Hegge Zijnen (1949) eredményeivel. A fúvókából kilépő sugár sebessége többnyire $51 \mathrm{~m} / \mathrm{s}$ volt, a fúvókából kilépő levegö sebességén, a fúvóka átméröjén és a közeg kinematikai viszkozitási tényezöjén alapuló Re Reynolds-szám $10^{5}$ nagyságrendủ volt, a fúvóka átméröje pedig $D=1,04$ inch $(26,416 \mathrm{~mm})$ volt. A levegősugár hömérsékletét $1{ }^{\circ} \mathrm{F}\left(0,556{ }^{\circ} \mathrm{C}\right)$ pontosságon belül állandó értéken tartották és a kilépő sugár turbulencia ingadozása $0,1 \%$ alatt volt. A mérés precizitására jellemző, hogy a levegőből eltávolították a $0,04 \mu \mathrm{m}$ átméröjünél nagyobb porszemeket is. Bár azóta a mérési technikák jelentősen fejlődtek, Wygnanski és Fiedler (1969) eredményeit ma is előszeretettel használják a szerzők saját mérési és számítási eredményeik validálására.

Panchapakesan és Lumley (1993) álló levegőbe érkező, függőlegesen felfelé áramló, forgásszimmetrikus levegősugárra vonatkozó nagy pontosságú kísérleti kutatás eredményeit mutatja be. A 6,1 mm átmérőjü fúvókából kilépő levegő sebességeloszlása homogénnek tekinthető (angolul „top-hat” sebességprofil), és a fúvóka kilépő keresztmetszetében lévő áramlás jellemzőin alapuló Reynolds-szám 
$\operatorname{Re}=11000$. A kísérleti berendezés kialakításánál ügyeltek arra, hogy minimális legyen az áramlási tér megzavarása és a hőmérséklet változása. A fúvókából kilépő levegősugár sebességét $0,05 \%$-os pontossággal tudták állandó értéken tartani, és ugyanott a turbulencia intenzitása mindössze $0,01 \%$ volt. A hődrótos anemométerrel mért három irányú sebességingadozásra, a Reynolds sebességre, a turbulens kinetikus energiára, illetve annak disszipációjára vonatkozó másod-, harmad- és negyedrendủ korrelációkat tartalmazó mérési eredményeiket összehasonlítva Capp és szerzőtársai (1990), Rodi (1975) és Wygnanski és Fiedler (1969) eredményeivel, jó egyezést tapasztaltak. Az általuk nyert magasabb rendủ korrelációk előnyösen felhasználhatók a turbulenciamodellek továbbfejlesztésére.

Mi és szerzőtársai (2001) dolgozatukban azt vizsgálják, hogy a fúvókából kilépő sebességprofil alakjának milyen hatása van a dimenziótlan átlagsebesség és egyéb turbulens jellemző eloszlások hasonlóságainak kialakulására. Az egyik vizsgált eset a homogén sebességeloszlás (angolul „top-hat”), a másik pedig a teljesen kialakult csőáramlás sebességprofilja. Az $\mathrm{Re}=16000$ Reynolds-szám esetén végrehajtott kísérleti vizsgálat során kimutatták, hogy a fúvóka közelében a két kilépö sebességprofil esetén jelentősen különböznek egymástól a dimenziótlan jellemzők. Ez a tanulmány alátámasztja George (1989) vizsgálati eredményeit abban, hogy a kilépő sebességprofil a teljes áramlási teret befolyásolja, és abban is, hogy az eloszlások hasonlósága csak a fúvókától távolabb lehetséges.

A kísérleti tanulmányok mellett számos numerikus vizsgálat is létezik a forgásszimmetrikus folyadéksugarak tulajdonságainak vizsgálatára. Ezek egyik jelentős példája Boersma és szerzőtársai (1998) dolgozata, amelyben direkt numerikus szimuláció (DNS) felhasználásával számítják a fúvókából nyugalomban lévő közegbe függőlegesen kilépő összenyomhatatlan közeg áramlási viszonyait $\mathrm{Re}=2400$ Reynolds-szám esetén. A szerzők a Navier-Stokes mozgásegyenletet és a kontinuitási egyenletet numerikus diszkretizáció alkalmazásával, turbulencia modellek alkalmazása nélkül oldják meg. Számítási eredményeiket más szerzők (például Wygnanski és Fiedler, 1969) Panchapakesan és Lumley, 1993) mérési eredményeivel összehasonlítva jó egyezést találtak.

Fukushima és szerzőtársai (2002) a forgásszimmetrikus szabad sugarakban lévő szennyezőanyag terjedésének kísérleti vizsgálatával foglalkoznak $\mathrm{Re}=2000$ Reynolds-szám esetén. A vízcsatornában végzett vizsgálathoz a PIV (Particle Image Velocimetry) és a LIF (Laser Induced Fluorescence) módszerek kombinációját használják. A fúvókától távolabb (a $d$ fúvókaátmérő (30-60)-szorosa tartományában) egy dimenziótlan sugár függvényében ábrázolva a mennyiségeket, azok eloszlásai a fúvókától mért távolságtól függetlenül egyetlen görbére estek, azaz a különböző keresztmetszetekben mért eloszlások egymáshoz hasonlóak. Mérési eredményeiket saját direkt numerikus szimulációs számítási (DNS) eredményeikkel és más szerzők kísérleti eredményeivel is összehasonlították és nagyon jó egyezést találtak.

Jelen dolgozatban azt kívánjuk megvizsgálni, hogy a fúvóka után, a különböző távolságokban lévő keresztmetszetekben fennáll-e a dimenziótlan turbulencia jellemzők hasonlósága egy olyan speciális fúvóka esetén, ahol a három irányból érkező levegősugár egy keverőtérben egyesül és így hagyja el a fúvókát. 


\section{A vizsgált mozgásjellemzők}

Amennyiben az áramlási tér egy pontjában $n$ darab sebességmérést végzünk a $v$ sebesség mindhárom $\left(v_{x}, v_{y}, v_{z}\right)$ komponensének meghatározására, akkor a mérési eredményekből az adott pontban az alábbi mozgásjellemzőket tudjuk kiszámítani:

A sebességértékek tekintetében:

- A sebességkomponensek átlagértékei:

$$
\begin{aligned}
& v_{x, \text { mean }}=\overline{v_{x}}=\frac{1}{n} \cdot \sum_{i=1}^{n} v_{x, i}, \quad v_{y, \text { mean }}=\overline{v_{y}}=\frac{1}{n} \cdot \sum_{i=1}^{n} v_{y, i}, \\
& v_{z, \text { mean }}=\overline{v_{z}}=\frac{1}{n} \cdot \sum_{i=1}^{n} v_{z, i} .
\end{aligned}
$$

- A sebességkomponensek ingadozásai:

$$
v_{x, i}^{\prime}=v_{x, i}-\overline{v_{x}}, \quad v_{y, i}^{\prime}=v_{y, i}-\overline{v_{y}}, \quad v_{z, i}^{\prime}=v_{z, i}-\overline{v_{z}} .
$$

- A sebességingadozások átlagértékei:

$$
\overline{v_{x}^{\prime}}=\frac{1}{n} \cdot \sum_{i=1}^{n} v_{x, i}^{\prime}, \quad \overline{v_{y}^{\prime}}=\frac{1}{n} \cdot \sum_{i=1}^{n} v_{y, i}^{\prime}, \quad \overline{v_{z}^{\prime}}=\frac{1}{n} \cdot \sum_{i=1}^{n} v_{z, i}^{\prime}
$$

- A sebességkomponensek szórásai, egyben az ingadozások négyzetes középértékei (rms):

$$
\begin{aligned}
& \sigma_{x}=v_{x, r m s}^{\prime}=\sqrt{\overline{v_{x}^{\prime 2}}}=\sqrt{\frac{1}{n} \cdot \sum_{i=1}^{n} v_{x, i}^{\prime 2}} \\
& \sigma_{y}=v_{y, r m s}^{\prime}=\sqrt{\overline{v_{y}^{\prime 2}}}=\sqrt{\frac{1}{n} \cdot \sum_{i=1}^{n} v_{y, i}^{\prime 2}} \\
& \sigma_{z}=v_{z, r m s}^{\prime}=\sqrt{\overline{v_{z}^{\prime 2}}}=\sqrt{\frac{1}{n} \cdot \sum_{i=1}^{n} v_{z, i}^{\prime 2}}
\end{aligned}
$$

- A sebesség átlagértéke:

$$
v_{\text {mean }}=\sqrt{v_{x, \text { mean }}{ }^{2}+v_{y, \text { mean }}^{2}+v_{z, \text { mean }}^{2}} .
$$

Az áramlás turbulencia jellemzői közül:

- A fajlagos turbulens kinetikus energia [J/kg]:

$$
k=\frac{1}{2} \cdot\left(\sigma_{x}^{2}+\sigma_{y}^{2}+\sigma_{z}^{2}\right)=\frac{1}{2} \cdot\left(\overline{v_{x}^{\prime 2}}+\overline{v_{y}^{\prime 2}}+\overline{v_{z}^{\prime 2}}\right) .
$$


- A turbulens sebesség lépték [m/s]:

$$
v^{\prime}=\sqrt{k}
$$

- A turbulencia fok:

$$
T_{u}=\frac{1}{v_{\text {mean }}} \cdot \sqrt{\frac{1}{3} \cdot\left(\overline{v_{x}^{\prime 2}}+\overline{v_{y}^{\prime 2}}+\overline{v_{z}^{\prime 2}}\right)}
$$

A méréseink és numerikus vizsgálataink során a fúvókából kilépő szabadsugárban e mennyiségek meghatározására helyeztük a hangsúlyt.

\section{A mérési elrendezés}

Méréseink során a hődrótos méréstechnikát (HWA), azon belül pedig az állandó hőmérsékletü légsebességmérő technikát (CTA) alkalmaztuk annak előnyös tulajdonságai miatt: alacsony zaj/jel arány, több kHz-es mintavételi frekvencia. A szonda pozicionálásához 3 tengelyű traverz-rendszert használtunk, amellyel 0,1 mmes térbeli felbontás is elérhető. A méréseket 2 dimenziós (két sebességkomponenst mérő) ún. szál-film szondával végeztük, $200 \mathrm{~Hz}$-es mintavételezési frekvenciával, amivel pontonként 1000 pillanatnyi sebesség-komponens értéket rögzítettünk. Az alkalmazott StreamWare nevü CTA méréstechnikai programból az időátlagolt sebességértékeket exportáltuk az egyes mérési pontok helykoordinátái szerint rendezve. Az adatok feldolgozása Excel-ben történt. A mérési elrendezést az alkalmazott koordinátarendszerrel a 2. ábra mutatja.

\section{2. ábra: A fúvóka és a mérőszonda elhelyezése}

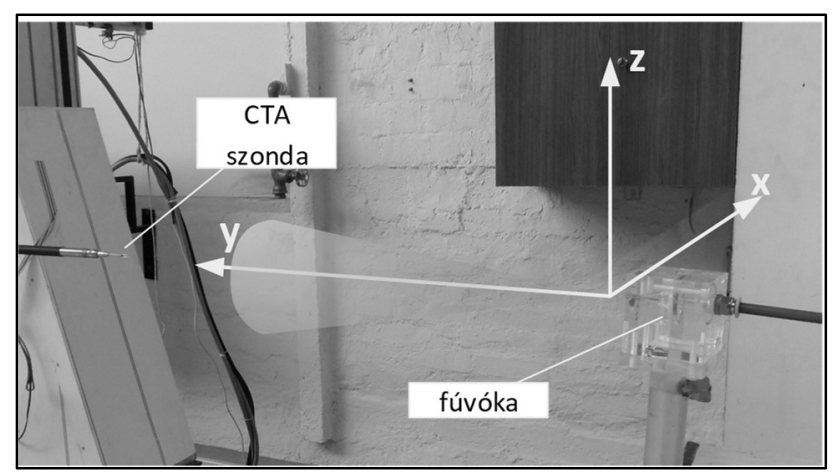

Forrás: A szerzők saját szerkesztése

A fúvókához a levegőt egy kompresszor szolgáltatta, a kompresszor és a fúvóka között egy nyomásszabályozó került beépítésre, amellyel konstans $p_{k}$ müködtető nyomás volt beállítható.

A szélesebb körü analízis céljából a müködtető nyomás hatását is vizsgáltuk $p_{k}=1,5$ bar, 2,0 bar és 2,5 bar értékek esetén. 
A vizsgálatok során két sebességkomponens mérése történt; egyrészt a légsugár tengelyének irányában ( $y$ koordináta), másrészt arra merőlegesen ( $x$ koordináta). A vizsgálat során három mérési sorozat készült:

- a légsugár tengelyében, a fúvókától távolodva ( $y=20$ mm-től y=600 mm-ig) a sebességcsökkenés detektálása;

- a fúvókától 200, 400 és 600 mm távolságra a vízszintes tengelysíkban, kereszt irányban ( $x$ irányban) sebességprofil mérések;

- a fúvókától 20,100,200, 300, 400, 500 és 600 mm távolságokban a függőleges tengelysíkban ( $z$ irányban), sebességprofil mérések.

\section{A numerikus szimuláció felépítése}

A fúvókában és az azt követő térrészben kialakuló áramlás modellezésére az AnsysFLUENT programrendszer platformján készítettük el a modellt. A vizsgált térrész felépítése: egy hengeres kialakítású $(\varnothing 80 \times 140 \mathrm{~mm})$ térrészen érkezik a levegő a fúvókához, amelyen az keresztülhalad, majd a fúvókát elhagyó levegő vizsgálatára (a mérések adatait már figyelembe véve) egy $\varnothing 500 \times 800 \mathrm{~mm}$ méretü hengeres térrészt alakítottunk ki.

A kialakított térrészt különböző típusú és elemszámú (1,9-3,5 millió cella) háló esetén megvizsgáltuk. Az érzékenységvizsgálat másik elemeként az időlépést változtattuk: $\Delta t=5 \cdot 10^{-3} \mathrm{~s}, 10^{-3} \mathrm{~s}, 5 \cdot 10^{-4} \mathrm{~s}$ és $10^{-4} \mathrm{~s}$. Vizsgáltuk továbbá a turbulencia modellek hatását is.

A számításaink során - a szakirodalom alapján - kezdetben a standard k- $\varepsilon$ modellt alkalmaztuk, de egyes kutatók (Moore és szerzőtársai (2017), Montazeri és szerzőtársai (2015)) szerint a „realizable $k-\varepsilon$ ” modell jobb közelítést ad, ezért a további turbulencia modelleket is megvizsgáltunk: a standard-, realizable- és az RNG $k-\varepsilon$ modellt, valamint a standard és SST $k-\omega$ modellt.

A mérésekkel való egyezést (validáció), a reális futtatási időt, a numerikus modell stabilitását is figyelembe véve a végleges modell fö jellemzői a következők: 3,4 millió cella, $\Delta t=10^{-3} \mathrm{~s}$ időlépés és standard $k-\varepsilon$ modell. A hálókialakítás egy részletét a 3. ábra mutatja.

\section{3. ábra: A hálófelépítés részlete}

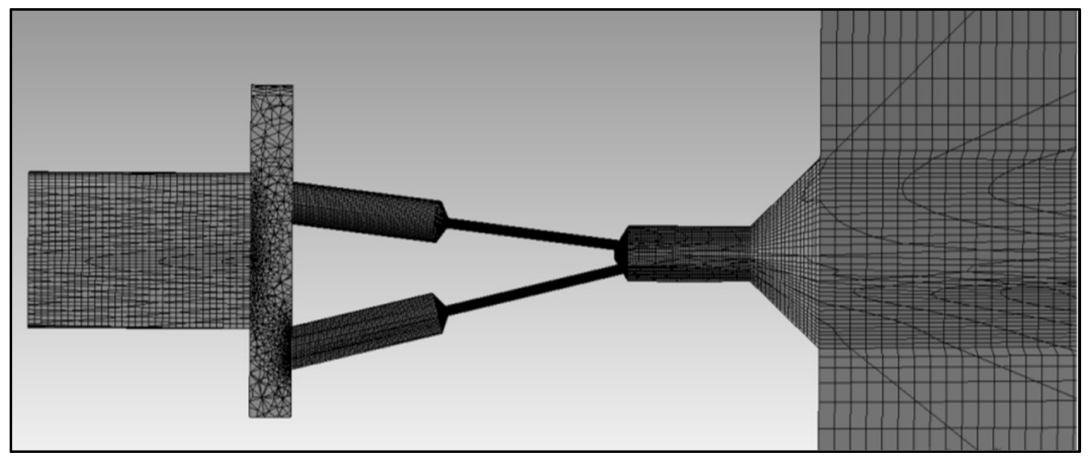

Forrás: A szerzők saját szerkesztése 


\section{Mérési eredmények}

Elsőként tekintsük az 1,5 bar, 2,0 bar és 2,5 bar nyomásokon a légsugár tengelyében a fúvókától távolodva (y=20-tól $600 \mathrm{~mm}$-ig) az átlagsebesség eloszlását (4. ábra). Megállapítható, hogy a fúvókától távolodva a sebesség mindhárom nyomáson exponenciálisan csökken.

4. ábra: A sebességeloszlás a fúvóka tengelyében

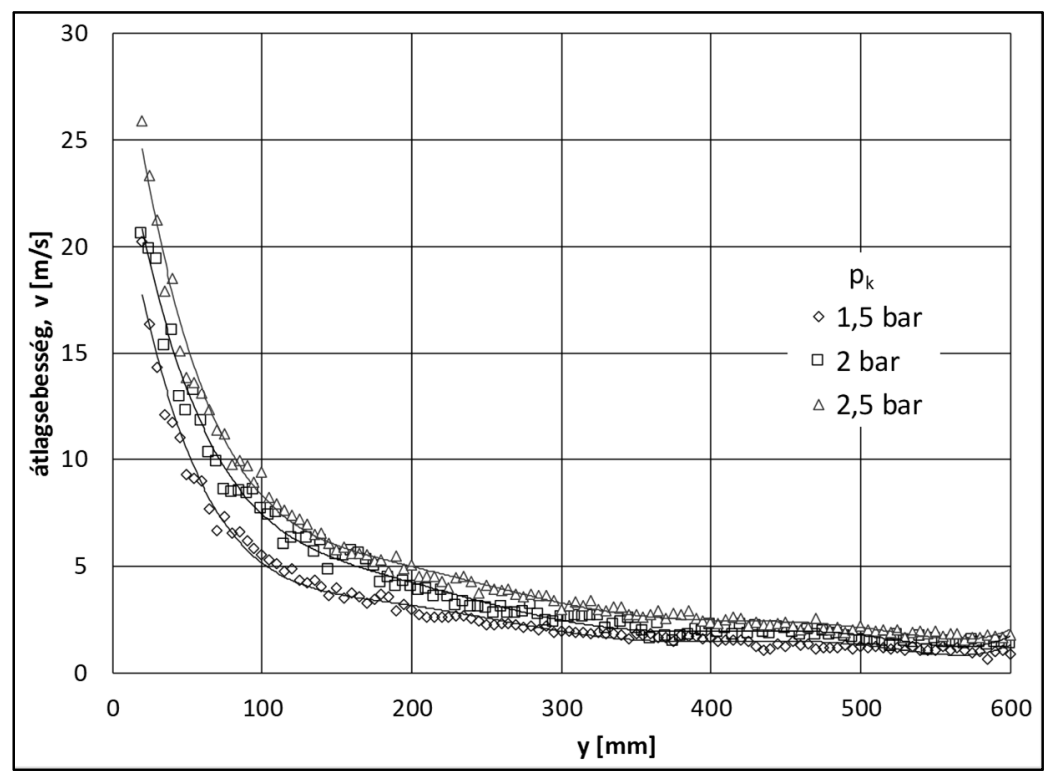

Forrás: A szerzők saját szerkesztése

A $v^{\prime}$ turbulens sebesség lépték ugyanitt a sebességcsökkenéssel arányos csökkenést mutatott a fúvókától távolodva, úgy ahogy azt az 5. ábra mutatja.

\section{5. ábra: A fúvóka tengelyében a turbulens sebesség lépték változása}

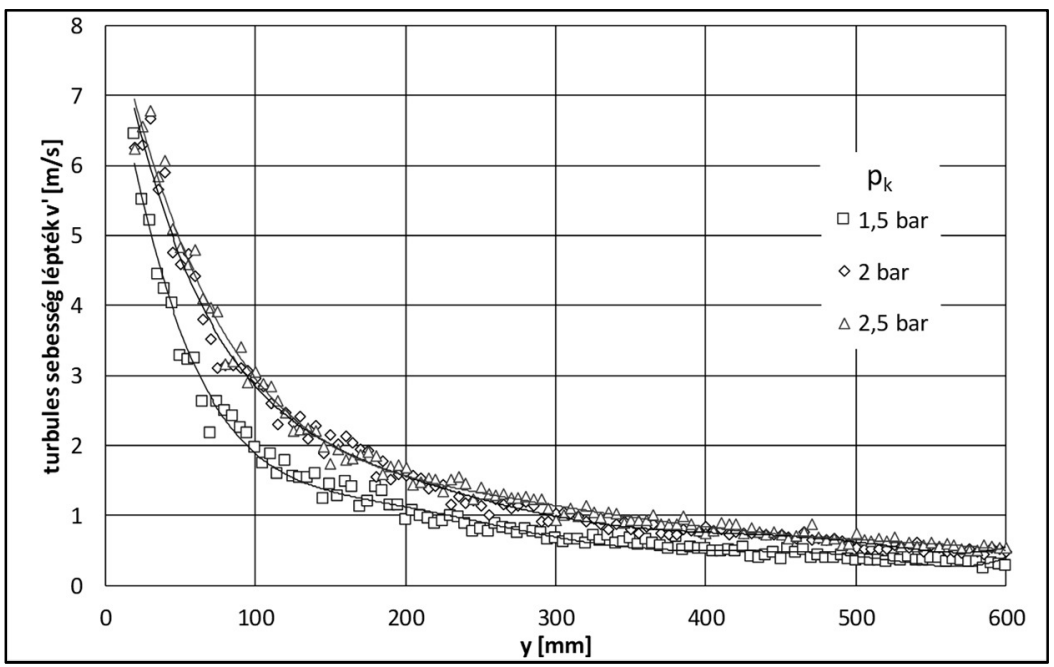

Forrás: A szerzők saját szerkesztése 
A turbulenciafok viszont a fúvókától mért távolsággal alig változott, értéke a müködtető nyomástól függetlenül 25 és $32 \%$ között alakult, amint az a 6. ábrán is látható.

\section{6. ábra: A fúvóka tengelyében a turbulenciafok változása}

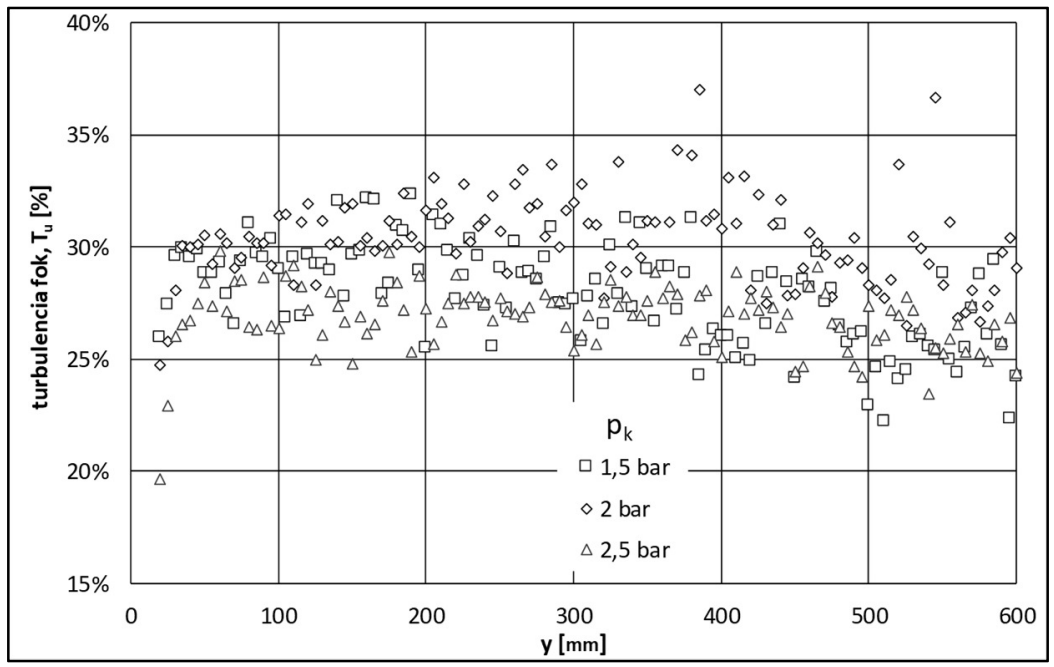

Forrás: A szerzők saját szerkesztése

A $k$ fajlagos turbulens kinetikus energia meredek csökkenés után, 200 mm-re a fúvókától, már gyakorlatilag $2 \mathrm{~J} / \mathrm{kg}$ alatti értékre csökkent és ezt követően már igen kevéssé változott. Igaz ez mindhárom vizsgált nyomásszint esetén, ezt igazolja a 7. ábra diagramja.

\section{7. ábra: A fúvóka tengelyében a fajlagos turbulens kinetikus energia változása}

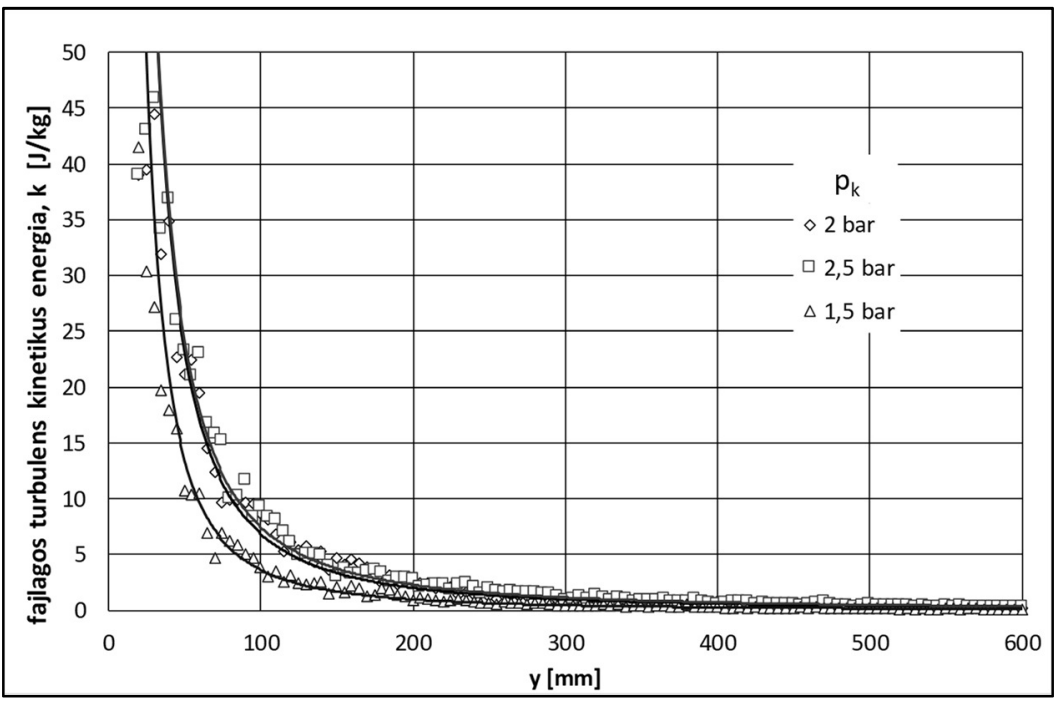

Forrás: A szerzők saját szerkesztése 
A számítási eredményekkel való egyezés tekintetében utalunk a következő fejezetben a 14. ábrára.

A tengelybeli sebességek mérése után a fúvókától távolodva $y=20,100,200$, 300, 400, 500, és 600 mm távolságokban a függőleges középsíkban $(y, z$ sík a 2. ábrán) végeztünk méréseket a sebességprofil meghatározására. $\mathrm{Az}$ adatok feldolgozása során figyelembe vettük a Fukushima és szerzőtársai (2000) cikkben ismertetett feldolgozási irányokat is. Eredményeinket 2 bar müködtetési nyomás esetére ismertetjük. A sebességprofilokat a 8 . ábra mutatja.

\section{8. ábra: Sebességprofilok a fúvókától távolodva $\left(p_{k}=\mathbf{2}\right.$ bar $)$}

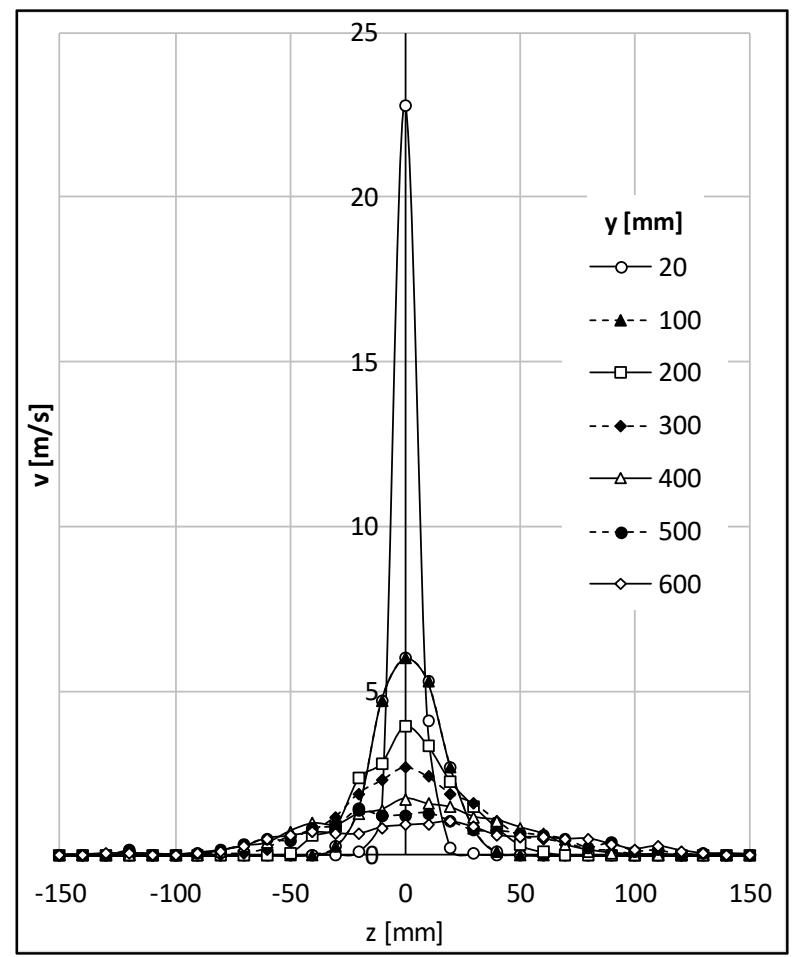

Forrás: A szerzők saját szerkesztése

A keresztirányban mért sebességeloszlás tekintetében megállapítottuk, hogy esetünkben is teljesül az idézett cikkben ismertetett hasonlóság, vagyis megfelelően dimenziótlanított koordináták esetén a sebességprofilok a fúvókától mért távolságtól függetlenek. A dimenziótlanítás a sebesség tekintetében a sebességprofil közepén érvényes $v_{0}$ átlagsebességgel történik. A tengelytől mért dimenziótlanított koordináta pedig:

$$
\eta=\frac{z}{y-y_{0}}
$$

ahol a fúvóka kilépő $d=4 \mathrm{~mm}$ átmérójével az irodalmi adatok szerint

$$
y_{0}=6,75 \cdot d
$$


A 9. ábrán a dimenziótlan sebességprofilokat látjuk. Az ábrából két dolog következik, egyrészt a mérési idő rövidsége miatt az adatok viszonylag nagy szórást mutatnak, másrészt a fúvóka némi geometriai aszimmetriája miatt a sebességprofil nem teljesen szimmetrikus. A méréseket ezért a későbbiekben az itt szerzett tapasztalatok alapján meg kívánjuk ismételni.

A dimenziótlan sebességprofil az irodalmi adatok szerint az alábbi Gausseloszlást követi:

$$
\frac{v}{v_{0}}(\eta)=e^{-K_{U} \cdot \eta^{2}}
$$

Panchapakesan és Lumley (1993) mérései alapján $K_{U}=75,2$ érték adódott, míg Boersma és szerzőtársai (1998) DNS numerikus szimulációval $K_{U}=76,1$ értéket számoltak. A 9. ábra tanúsága szerint esetünkben is az említett aszimmetriától eltekintve az egyezés kimutatható $K_{U} \approx 70$ érték mellett.

\section{9. ábra: A fúvóka tengelyében különböző $\boldsymbol{y}$ távolságokban mért sebesség profilok a Gauss-eloszlást követik $\left(p_{k}=2\right.$ bar $)$}

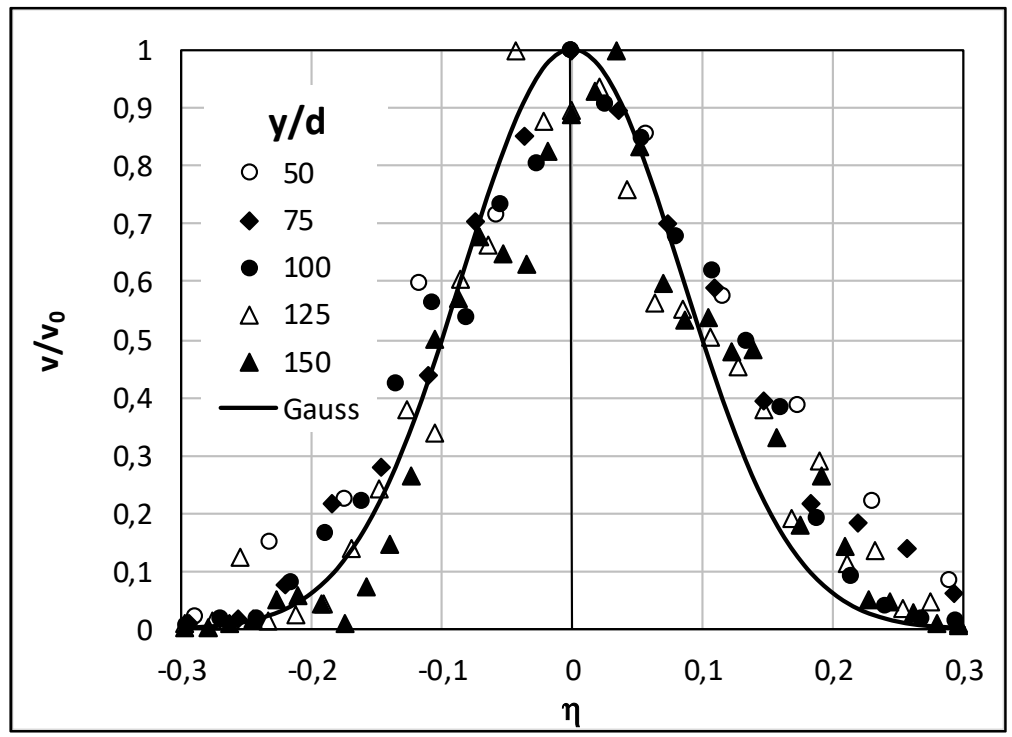

Forrás: A szerzők saját szerkesztése

A tapasztalt aszimmetria a következőkben ismertetett jellemzőkre is öröklödik. Az aszimmetriától és a szórástól függetlenül a jellemzők jól illeszkednek az irodalmakban bemutatott eloszláshoz, ahogy azt a 10. ábrán nyomon követhetjük. 


\section{0. ábra: A fúvóka tengelyében különböző $\boldsymbol{y}$ távolságokban mért}

sebességprofilok összehasonlítva irodalmi adatokkal

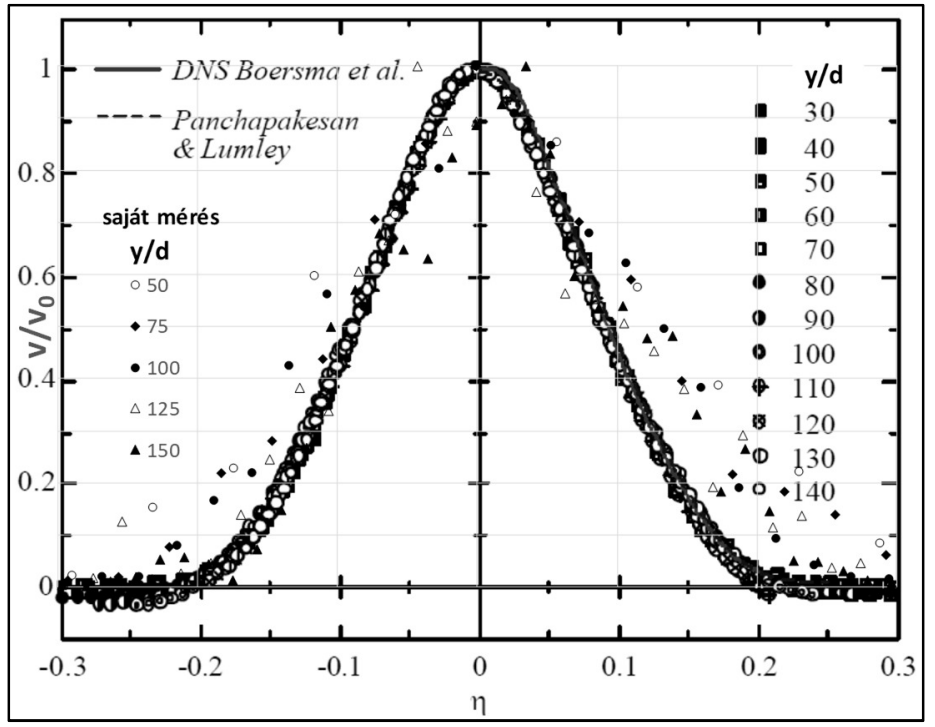

Forrás: Fukushima és szerzőtársai (2002) felhasználásával a szerzők saját szerkesztése

A turbulens sebességléptéket a sugár középpontbeli értékkel dimenziótlanítva szintén a fúvókától mért távolságtól döntően független eloszlást kapunk (lásd 11 . $a ́ b r a)$. Igaz ez a turbulens kinetikus energiára is (amennyiben a dimenziótlanítást hasonló módon oldjuk meg), mint ezt a 12. ábra diagramja is mutatja.

\section{1. ábra: A fúvóka tengelyében különböző $\boldsymbol{y}$ távolságokban mért sebesség} profilok turbulens sebességléptékei $\left(p_{k}=2\right.$ bar $)$

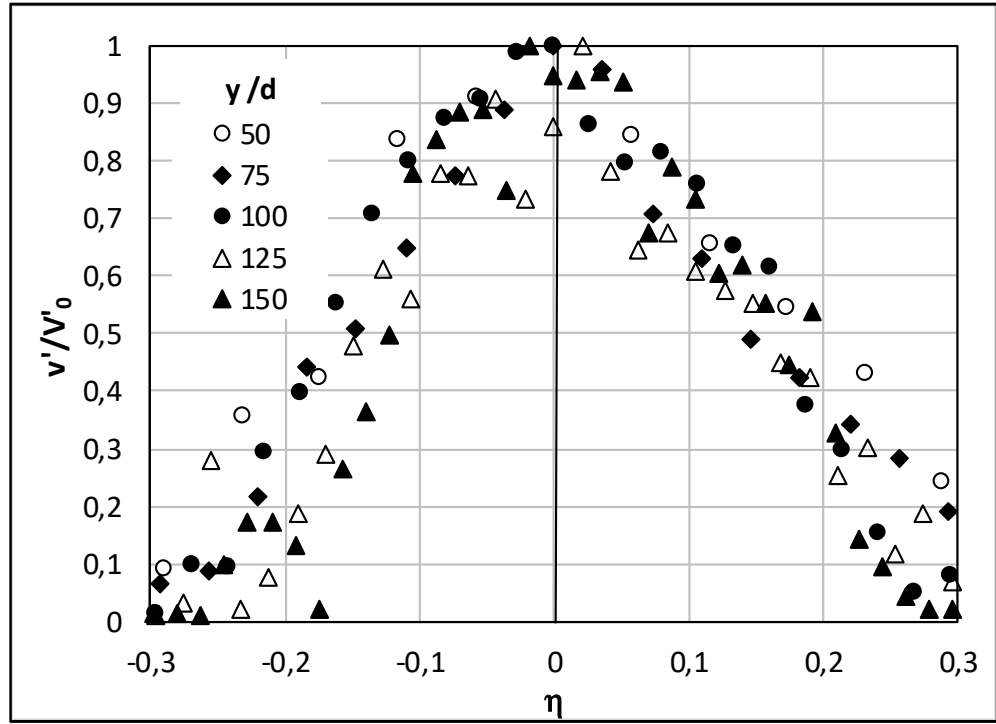

Forrás: A szerzők saját szerkesztése 
12. ábra: A fúvóka tengelyében különböző $\boldsymbol{y}$ távolságokban az áramlás turbulens kinetikus energiájának eloszlása ( $p_{k}=2$ bar)

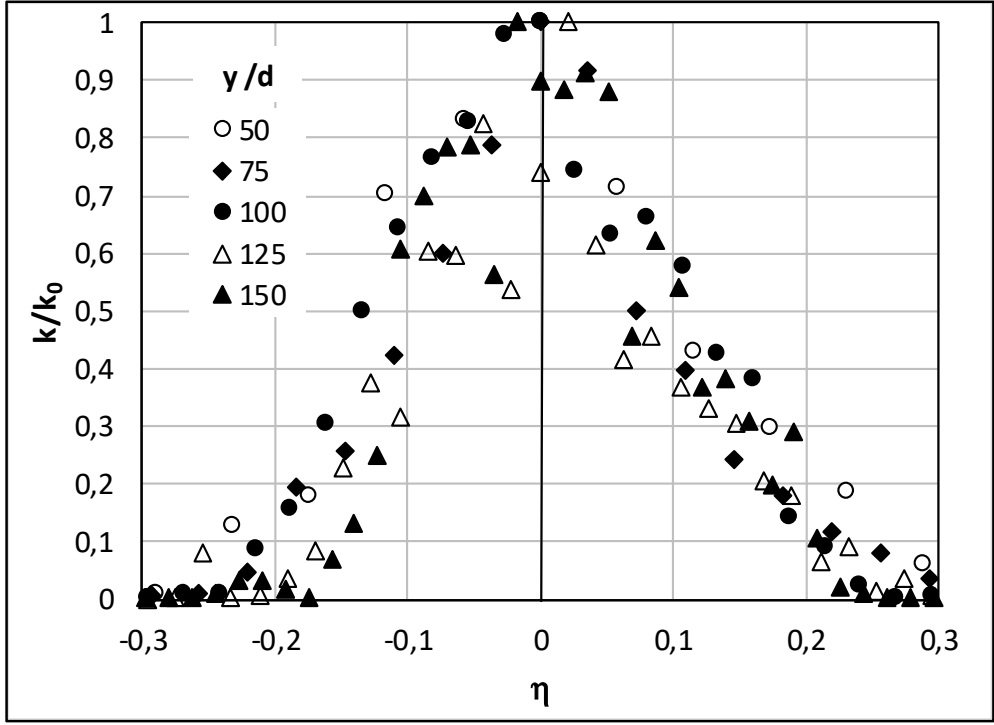

Forrás: A szerzők saját szerkesztése

A turbulenciafok adott $y$ távolság esetén a sugár tengelyében a legalacsonyabb, jellemzően 30-50\% közötti a különböző esetekben. A tengelytől távolodva kezdetben enyhén növekszik, majd $|\eta|>0,15$ tengelytől mért dimenziótlan távolság értéktől kezdve intenzíven nő, sőt nagyobb $\eta$ értékek esetén jelentős ingadozást mutat. Mindezek oka a sugárszéleken jelentkező intenzív keveredés a környezeti levegővel. Ezt mutatja a 13. ábra.

\section{3. ábra: A turbulenciafok eloszlása a fúvóka tengelyében különböző $\boldsymbol{y}$ távolságokban $\left(p_{k}=2\right.$ bar $)$}

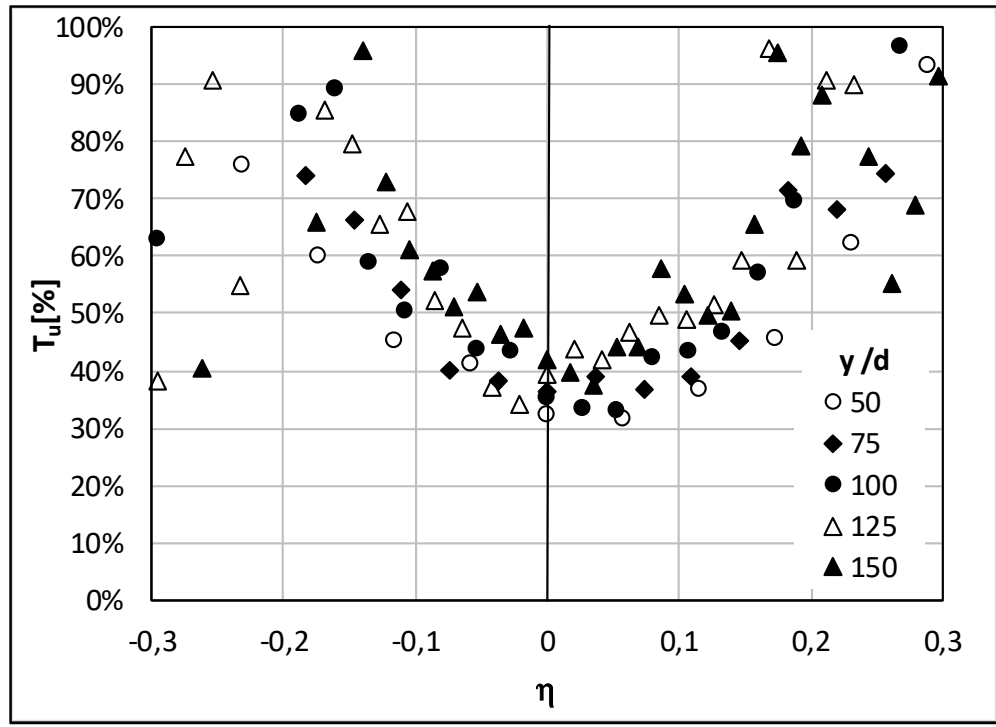

Forrás: A szerzők saját szerkesztése 
Úgy tűnik, hogy a fentiekben bemutatott hasonlóság nem függhet jelentősen azon Reynolds-számtól, amelyet a fúvókából kilépő gázsebességből, a fúvóka kilépő átméröjéből és a kilépő levegősugár viszkozitásából számolunk. Panchapakesan és Lumley (1993) bemutatott cikkében 5 különböző szerző esetén a fúvókából kilépő sugár sebessége $U_{0}=27-101 \mathrm{~m} / \mathrm{s}$ között változott, az alkalmazott fúvókák átméröje $d=6,1-25,4 \mathrm{~mm}$ volt, a Re szám pedig $10^{4}-10^{5}$ tartományba esett. Fukushima és szerzőtársai (2002) szintén ezt a hasonlóságot igazolták megint más üzemi körülmények között: $U_{0}=2 \mathrm{~m} / \mathrm{s}, d=1 \mathrm{~mm}, R e=2000$. Esetünkben ezen adatok $U_{0}=20 \mathrm{~m} / \mathrm{s}, d=4 \mathrm{~mm}, \operatorname{Re}=5200$, tehát jelentősen különbözők.

Panchapakesan és Lumley (1993) foglalkozik azzal a kérdéssel, hogy a levegősugár tengelyében az $U_{0} / U_{m}$ dimenziótlan reciprok sebesség $\left(U_{0}\right.$ a kilépő sebesség, $U_{m}$ pedig a sugártengelyben a sebesség) hogyan változik a fúvókától távolodva a levegősugár tengelyében. Erre szabályt mutat be: két egyenes szakasszal írja le az eloszlást. Megvizsgáltuk az adatrendszerüket és megállapítottuk, hogy egyetlen másodfokú görbével sokkal jobban közelíthető a vonatkozó eloszlás. Mindezt mutatja a 14. ábra.

\section{4. ábra: A reciprok sebességeloszlás közelítése két egyenessel az irodalomban, és a mi közelítésünk egyetlen másodfokú görbével}

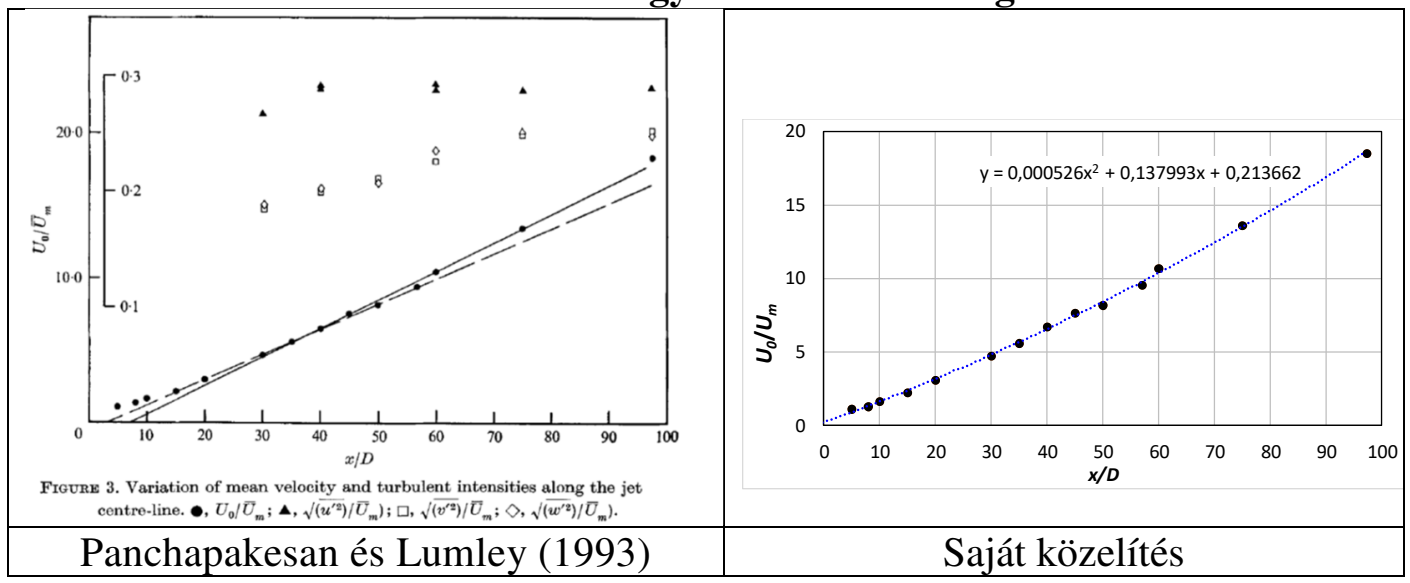

Forrás: Panchapakesan és Lumley (1993) felhasználásával a szerzők saját szerkesztése

A mi mérési eredményeinkre is meghatároztuk ezt a görbét mindhárom kompresszornyomás esetére. Itt a 15. ábra 2 bar müködtető nyomás esetére mutatja a mérési adatokat és a rá fektetett másodfokú görbét. A mérési adatok a fúvókától távolodva, a sugár gyengülésével egyre nagyobb szórást mutatnak, de a tendencia kellően felismerhető. 
15. ábra: A reciprok sebességeloszlás $\left(\boldsymbol{p}_{k}=\mathbf{2}\right.$ bar $)$

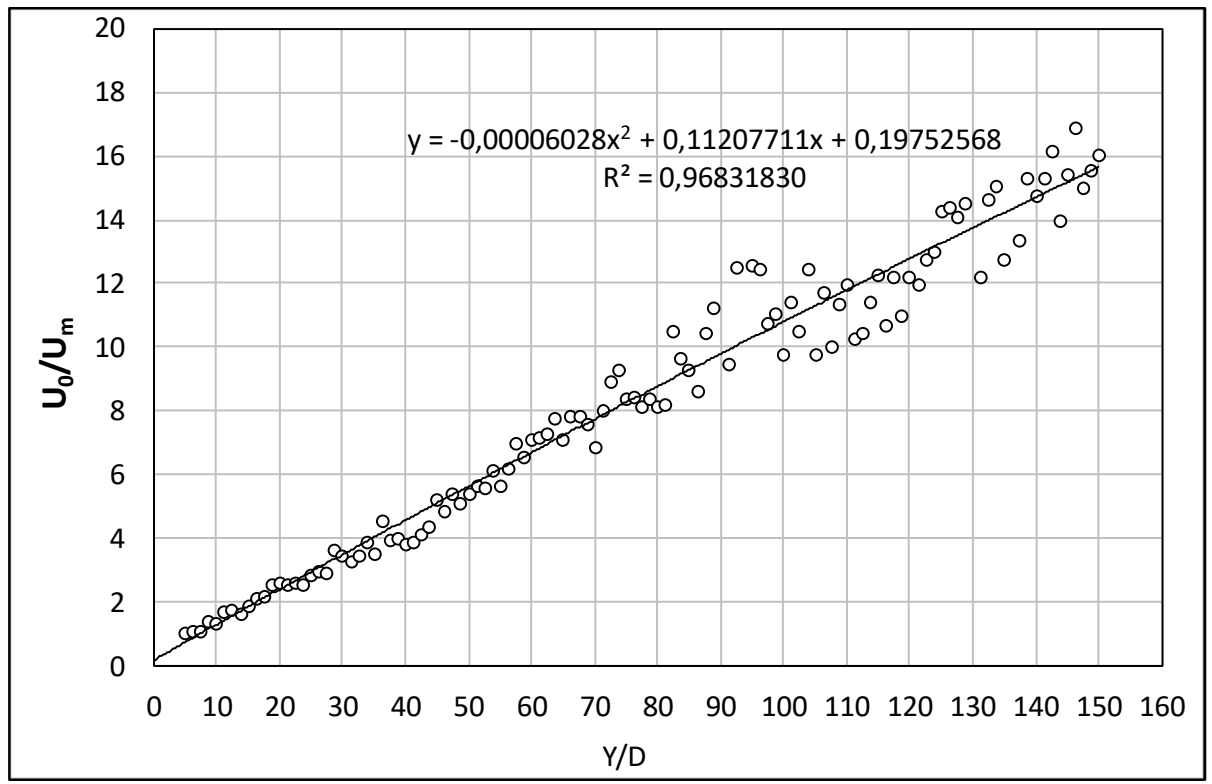

Forrás: A szerzők saját szerkesztése

\section{A numerikus modellezés eredményei}

Itt közöljük a mérés és a numerikus számítás összevetéséből adódó eredményeket, amelyek a tengelybeli sebességek tekintetében kiváló egyezést mutatnak, ahogy azt 2 bar müködtető nyomás esetére a 16. ábra diagramján követhetjük. A turbulens jellemzők közül a fajlagos turbulens kinetikus energia tengelybeli eloszlását láthatjuk a mérési és a számítási eredmények alapján a 17. ábrán. Az egyezés itt is meggyőző.

16. ábra: A fúvóka tengelyében a mért és a számított sebességek eloszlása $\left(p_{k}=\mathbf{2}\right.$ bar)

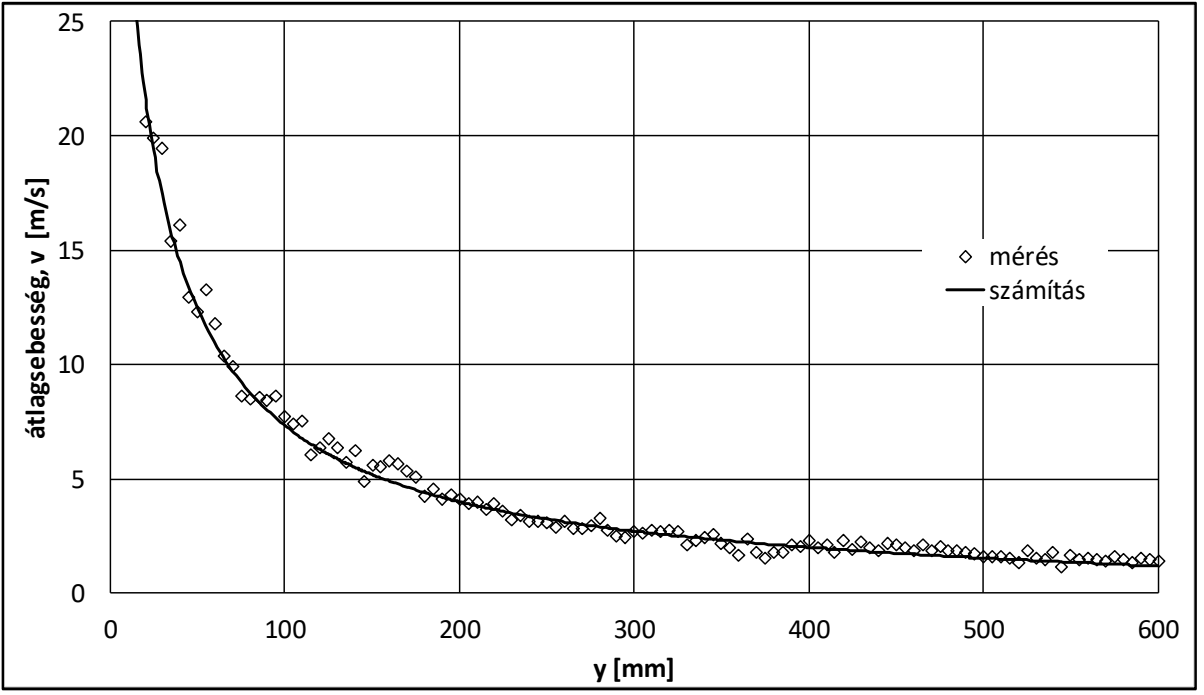

Forrás: A szerzők saját szerkesztése 
17. ábra: A fajlagos turbulens kinetikus energia alakulása a fúvóka tengelye mentén $\left(p_{k}=2\right.$ bar $)$

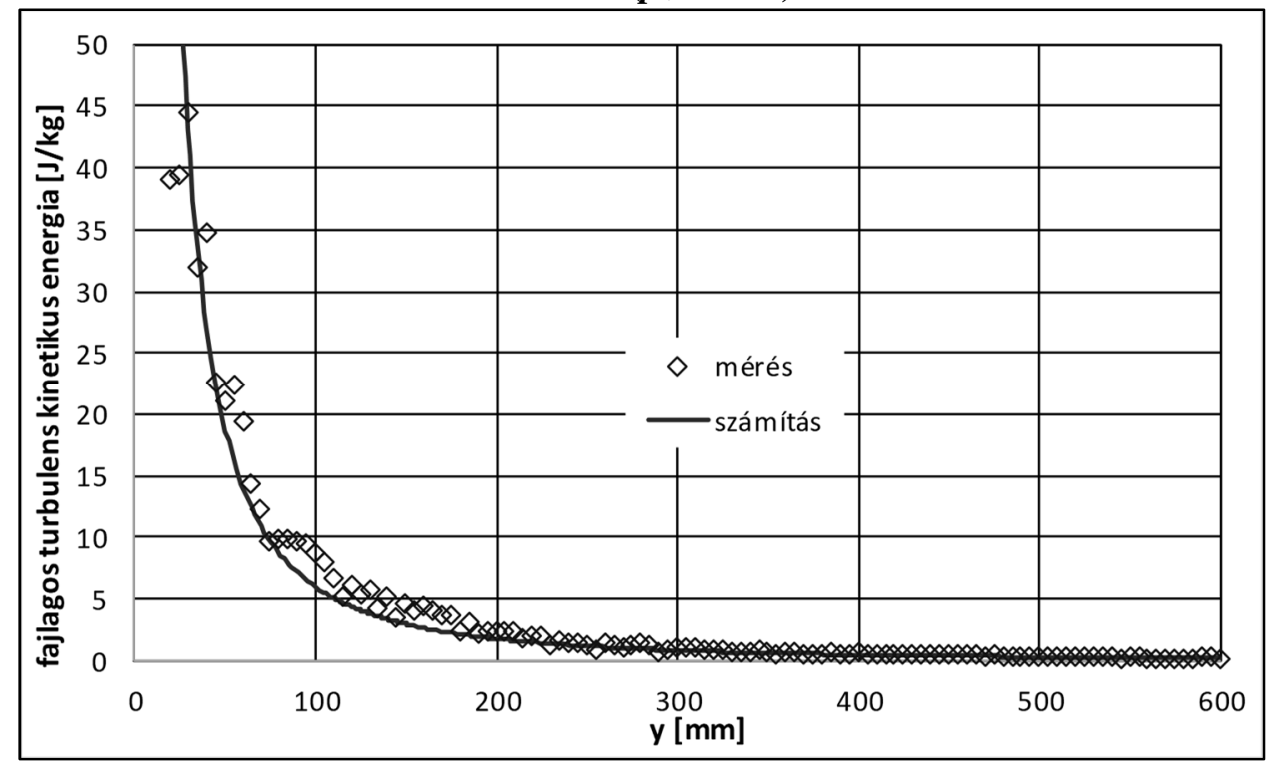

Forrás: A szerzők saját szerkesztése

Ezeken túlmenően a numerikus szimuláció lehetőséget biztosított az áramlás finomstruktúrájának megismerésére is. Példaként a 18. ábrán az áramlás középsíkjában a sebességeloszlás látható 2 bar müködtető nyomás esetén. Jól követhető a sugárhatár és a sugár magjában a sebesség intenzív csökkenése.

18. ábra: Az átlagsebességeloszlás [m/s] a levegősugár középsíkjában $\left(p_{k}=2\right.$ bar $)$

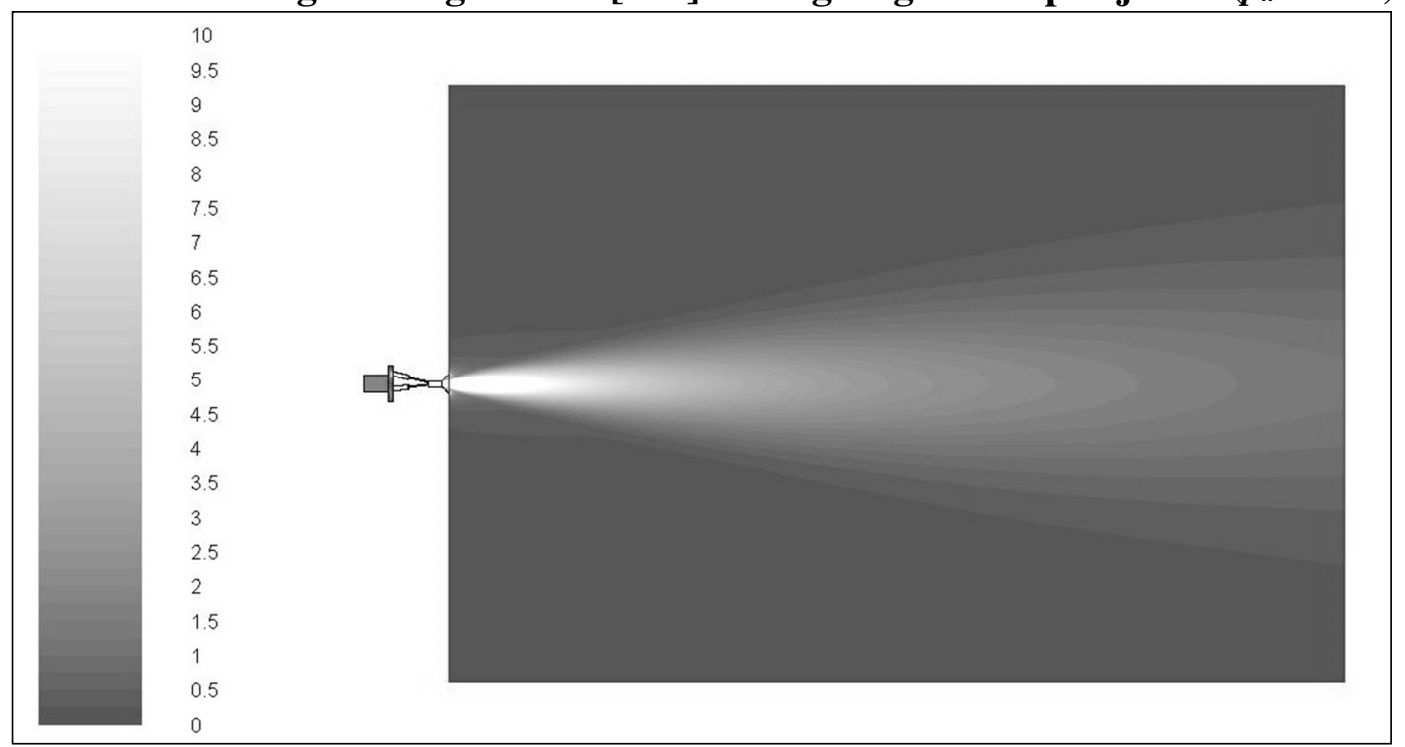

Forrás: A szerzők saját szerkesztése 


\section{8. Összegzés}

A vizsgált különleges kialakítású fúvóka tekintetében is megállapítható volt az irodalomban számos szerző által tapasztalt - a sebesség és a turbulencia jellemzők eloszlására vonatkozó - hasonlóság. E fúvóka tekintetében viszont a mérési értékekben jelentősebb szórás és aszimmetria mutatkozott. Ennek több valószínűsíthető oka is van. Az első az, hogy az egyedi gyártású fúvóka belső szerkezete sem tökéletesen szimmetrikus, a kisméretü járatok geometriai jellemzői (a 3 tápcsatorna átmérője és dőlésszöge) is szórást mutatnak. A másik ok az alkalmazott mérési eljárásban keresendő. Valószínüsíthető, hogy a némileg pulzáló áramlás átlagértékeinek pontos meghatározásához hosszabb mintavételezési időre lett volna szükség. Ezt igazolták a vizsgálatot követő mérési kísérletek is melyeket szintén $200 \mathrm{~Hz}$-es mintavételezési frekvenciával, de pontonként 2000 pillanatnyi sebesség-komponens rögzítésével végeztünk. E tapasztalat alapján a vizsgálataink folytatásaként a mintavételezés kellő megválasztására nagyobb hangsúlyt kívánunk fektetni. Bár a számítások a mérésekkel kellő egyezést mutattak, a numerikus elemzéseket is folytatni kívánjuk. Ennek kiemelt iránya a levegősugárhoz a szekunder fúvókán folyadék hozzákeverése lesz.

\section{Köszönetnyilvánítás}

A kutató munka az Európai Unió és a magyar állam támogatásával, az Európai Regionális Fejlesztési Alap társfinanszírozásával, a GINOP-2.3.4-15-2016-00004 projekt keretében valósult meg, a felsőoktatás és az ipar együttmüködésének elősegítése céljából.

\section{Irodalomjegyzék}

Boersma, B.J., Brethouwer, G. and Nieuwstadt, F.T,M. (1998): A numerical investigation on the effect of the inflow conditions on the self-similar region of a round jet. Physics of Fluids 10 (4), 899-909.

Capp, S.P., Hussein, H.J., and George, W.K (1990): Velocity measurements in a high Reynolds number, momentum-conserving, axisymmetric, turbulent jet. Tech. Rep. 123., Turbulence Research Laboratory, University at Buffalo, SUNY.

Fukushima, C., Aanen, L., Westerweel, J. (2002): Investigation of the Mixing Process in an Axisymmetric Turbulent Jet Using PIV and LIF. in: Laser Techniques for Fluid Mechanics: Selected Papers from the 10th International Symposium Lisbon, Portugal July 10-13, 2000, (Eds.: Adrian, R.J., Durao, D., Heitor, M.V., Maeda, M., Tropea, C., Whitelaw, J.H.), pp. 339356. Springer, 2002.

George, W. K. (1989): The self-similarity of turbulent flows and its relation to initial conditions and coherent structures. In Recent Advances in Turbulence (ed. R. E. A. Arndt \& W. K. George), pp. 39-73. Hemisphere.

Hinze, J.O., and Van Der Hegge Zijnen (1949): Transfer of heat and matter in the turbulent mixing zone of an axially symmetrical jet. Flow, Turbulence and Combustion 1 (1949), 43-

Mi, J., Nobes, D.S., and Nathan, G.J. (2001): Influence of jet exit conditions on the passive scalar field of an axisymmetric free jet. Journal of Fluid Mechanics 432, 91-125.

Montazeri, H., Blocken, B., and Hensen J.L.M. (2015): Evaporative cooling by water spray systems: CFD simulation, experimental validation and sensitivity analysis. Building and Environment 83, 129-141. 
Moore, B., Nabhani, F., Askari, V. (2017): Sensitivity analysis of spray painting process to input parameters: Validation of CFD jet impingement model against an experimental dataset. Robotics and Computer-Integrated Manufacturing 47, 11-16.

Panchapakesan, N.R. and Lumley, J.L. (1993): Turbulence measurements in axisymmetric jets of air and helium. Part 1. Air jet. Journal of Fluid Mechanics 246, 197-223.

Reichardt, H. (1942): Gesetzmassigkeiten der freien Turbulenz. VDI-Forschungsheft 414.

Rodi, W. (1975): A new method of analyzing hot-wire signals in highly turbulent flow and its evaluation in a round jet. DNA Information 17.

Wygnanski, I. and Fiedler, H. (1969): Some measurements in the self-preserving jet. Journal of Fluid Mechanics 38 (3), 577-612. 